\title{
Candidate Defense Genes from Rice, Barley, and Maize and Their Association with Qualitative and Quantitative Resistance in Rice
}

\author{
J. Ramalingam, ${ }^{1}$ C. M. Vera Cruz, ${ }^{2}$ K. Kukreja, ${ }^{1}$ J. M. Chittoor, ${ }^{1}$ J.-L. Wu, ${ }^{2}$ S. W. Lee, ${ }^{1}$ M. Baraoidan, ${ }^{2}$ \\ M. L. George, ${ }^{2}$ M. B. Cohen, ${ }^{2}$ S. H. Hulbert, ${ }^{1}$ J. E. Leach, ${ }^{1}$ and H. Leung ${ }^{2}$ \\ ${ }^{1}$ Department of Plant Pathology, 4024 Throckmorton Plant Sciences Center, Kansas State University, Manhattan $66506-$ \\ 5502, U.S.A.; ${ }^{2}$ Entomology and Plant Pathology Division, International Rice Research Institute, DAPO Box 7777, Metro \\ Manila, Philippines
}

Submitted 7 June 2002. Accepted 6 September 2002.

Candidate genes involved in both recognition (resistance gene analogs [RGAs]) and general plant defense (putative defense response [DR]) were used as molecular markers to test for association with resistance in rice to blast, bacterial blight (BB), sheath blight, and brown plant-hopper (BPH). The 118 marker loci were either polymerase chain reaction-based RGA markers or restriction fragment length polymorphism (RFLP) markers that included RGAs or putative DR genes from rice, barley, and maize. The markers were placed on an existing RFLP map generated from a mapping population of 116 doubled haploid (DH) lines derived from a cross between an improved indica rice cultivar, IR64, and a traditional japonica cultivar, Azucena. Most of the RGAs and DR genes detected a single locus with variable copy number and mapped on different chromosomes. Clusters of RGAs were observed, most notably on chromosome 11 where many known blast and $\mathrm{BB}$ resistance genes and quantitative trait loci (QTL) for blast, BB, sheath blight, and BPH were located. Major resistance genes and QTL for blast and BB resistance located on different chromosomes were associated with several candidate genes. Six putative QTL for BB were located on chromosomes 2, 3, 5, 7, and 8 and nine QTL for BPH resistance were located to chromosomes 3, 4, 6, 11, and 12. The alleles of QTL for BPH resistance were mostly from IR64 and each explained between 11.3 and $20.6 \%$ of the phenotypic variance. The alleles for $B B$ resistance were only from the Azucena parent and each explained at least $8.4 \%$ of the variation. Several candidate RGA and DR gene markers were associated with QTL from the pathogens and pest. Several RGAs were mapped to BB QTL. Dihydrofolate reductase thymidylate synthase co-localized with two BPH QTL associated with plant response to feeding and also to blast QTL. Blast QTL also were associated with aldose reductase, oxalate oxidase, JAMyb (a jasmonic acid-induced Myb transcription factor), and peroxidase markers. The frame map provides reference points to select candidate genes for cosegregation analysis using other mapping populations, isogenic lines, and mutants.

Corresponding author: Jan E. Leach, Telephone: +1-785-532-1367; Fax: +1-785-532-5692; E-mail: jeleach@ksu.edu

J. Ramalingam, C. M. Vera Cruz, and K. Kukreja contributed equally.

* The e-Xtra logo stands for "electronic extra" and indicates the HTML abstract available on-line contains supplemental material not included in the print edition. There are two extra figures and an extra table available on-line.
Efficiency of marker-aided selection in breeding programs depends on the strength of linkage between molecular markers and the target trait. Traditionally, anonymous molecular markers are used to establish linkage with a phenotype. However, even for tightly linked markers, the effectiveness of markeraided selection is greatly diminished by the occasional uncoupling of the marker from the trait during many cycles of meiosis in a breeding program. With the availability of large genome databases, it is now possible to predict putative function of a gene based on sequence information, thus enabling the identification of candidate genes involved in a particular biochemical pathway. These candidate genes, or DNA sequences with predicted function, are used as molecular markers to associate with phenotypes expressed in segregating populations or genetic stocks (Huh et al. 2001; Thorup et al. 2000).

The candidate gene approach has been particularly productive for the investigation of pest and disease resistance because many genes involved in these resistance pathways have been characterized. Candidate genes involved in defense responses can be broadly classified as (i) those involved in the initial recognition of pest or pathogen, the resistance (R) genes, and (ii) those involved in defense response (DR) triggered by the recognition event (Dixon and Harrison 1990). Candidate genes for $\mathrm{R}$ and DR genes are also potential candidates for insect resistance genes. The nucleotide binding site-leucine rich repeat (NBS-LRR) class of R gene has been demonstrated to include resistance to the full taxonomic range of plant pests, including viruses, bacteria, fungi, oomycetes, and nematodes (Hulbert et al. 2001). Resistance in tomato to the potato aphid also is controlled by this class of genes (Rossi et al. 1998; Vos et al. 1998). Pioneering work with candidate gene mapping for insect resistance has implied that the genes involved in flavone biosynthesis contribute to corn ear worm resistance in maize (Byrne et al. 1996). Biosynthesis of similar types of compounds commonly is induced in defense reactions and genes affecting their biosynthesis have been demonstrated to contribute to defense after expression in transgenic plants (Dixon 2001; Epple et al. 1997; Hain et al. 1993; McMullen et al. 1998; Wu et al. 1997). Recent work indicates that plant responses to phloem-feeding insects such as aphids and whiteflies have similarities to plant responses to pathogens (Walling 2000).

The resistance genes identified thus far share common sequence motifs, such as LRRs, NBSs, and kinase domains, reflecting related functions in their roles in pathogen recognition (Anderson et al. 1997; Bent et al. 1994; Hulbert et al. 2001). These motifs have been widely used to design degenerate oli- 
gonucleotide primers to isolate $\mathrm{R}$ gene analogs (RGAs) by polymerase chain reaction (PCR) amplification (Garcia-Mas et al. 2001; Kanazin et al. 1996; Mago et al. 1999; Yu et al. 1996). As a result, a sizable collection of PCR-derived NBS-LRR sequences from diverse plant species is now available. Many of these sequences have been located to chromosomal regions containing major $\mathrm{R}$ genes as well as quantitative trait loci (QTL). Leister and associates (1998) isolated NBS-LRR sequences from rice and barley and found a majority of these sequences mapped to regions containing known major $\mathrm{R}$ genes in cereal crops. Similarly, Collins and associates (1998) demonstrated co-localization of NBS-LRR sequences to rust resistance gene loci ( $R p 1$ and $R p 3)$ in maize. Some candidate $\mathrm{R}$ genes also co-localize with disease resistance QTL, supporting the idea that some major $\mathrm{R}$ genes also contribute to quantitative resistance. For example, RGAs co-localized with anthracnose-specific QTL in common bean (Geffroy et al. 2000), to QTL associated with resistance to stripe rust and Barley yellow dwarf virus in barley (Toojinda et al. 2001), and to partial resistance to Cucumber mosaic virus in pepper (Pflieger et al. 1999). In most cases, however, the resolution of QTL mapping is low and, thus, definitive association between NBS-LRR sequences and QTL is difficult to establish.

Although the NBS-LRR sequences govern recognition in plant-pathogen interactions, the DR genes generally are considered downstream from the recognition step of the signal transduction pathway. Thus, DR genes include a variety of genes that are recognized based on their increased expression during the defense response and whose products are thought to enhance defense in a quantitative manner (McMullen and Simcox 1995; Wang et al. 1994; Young 1996). The proteins encoded by DR genes include (i) structural proteins that are incorporated into the extracellular matrix and participate in the confinement of the pathogen; (ii) enzymes of secondary metabolism, such as members of the phenylpropanoid pathway important in the synthesis of isoflavonoid and stilbene phytoalexins and lignin; (iii) enzymes that are implicated to be directly involved in the defense response, including chitinases, peroxidases, catalases, glucanases, sulfotransferases, and proteins that inactivate fungal ribosomes or bind chitin; and (iv) regulatory genes controlling the expression of multiple downstream DR genes (Dixon and Harrison 1990).

Some of the DR genes are members of gene families, with only one or a few of the family members likely participating in defense (e.g., peroxidases in rice; Chittoor et al. 1997). Of relevance to this study, there is sufficient sequence similarity among these gene family members across species and genera that some DR genes can be used to hybridize to homologs in related plant species (Boyko et al. 2002; Faris et al. 1999; Trognitz et al. 2002). For example, using part of the Kansas State University defense gene collection of DR genes, Faris and associates (1999) demonstrated that several candidate DR genes, including oxalate oxidase, peroxidase, superoxide dismutase, chitinase, and thaumatin, from various cereals were associated with disease resistance QTL in wheat.

To systematically associate function with available candidate gene sequences from multiple species, it would be useful to locate them onto a frame map with a maximal amount of phenotypic information. Simply locating candidate genes to chromosomal regions with mapped phenotypes does not confirm the function of the gene; however, this approach provides an efficient way to narrow down a few candidate sequences that can be tested by detailed genetic analyses using appropriate mapping populations and mutants (Collins et al. 1998).

In rice, a doubled haploid (DH) population derived from two cultivars, IR64 and Azucena, provides a useful reference population for mapping candidate genes (Guiderdoni et al.
1992). The two parental lines are highly diverged and exhibit contrasting phenotypes in a variety of agronomic traits. IR64 is a popular improved indica cultivar grown in tropical Asia and has a large number of qualitative and quantitative resistance genes against major rice diseases and against the insect pest brown planthopper (BPH). Azucena is a traditional japonica cultivar with quality factors and tolerance to abiotic stresses. This DH population has been used for mapping disease (Albar et al. 1998; Prashanth et al. 1998; Wang et al. 2001) and insect resistance (Alam and Cohen 1998) as well as tolerance to drought (Courtois et al. 2000).

The main objective of this study is to use the DH mapping population to locate markers derived from conserved regions of NBS-LRR-containing $\mathrm{R}$ genes and DR genes from rice, maize, and barley, and examine if any candidate genes co-localized with disease and insect resistance. The positions of QTL for rice blast and sheath blight on this $\mathrm{DH}$ population were previously reported (Prashanth et al. 1998; Wang et al. 1994; Zou et al. 2000); in this communication, we report several positions for putative bacterial blight (BB) and BPH QTL. By placing candidate genes into defined chromosomal regions and determining their association with disease and insect QTL, we provide a useful resource from which sequences can be efficiently selected for investigating biological function and for use in breeding programs for disease and pest resistance.

\section{RESULTS}

Polymorphism of candidate genes as molecular markers.

Consistent with previous reports (Chen et al. 1998), PCRbased markers derived using RGA primers were polymorphic and informative, that is, every primer pair produced scorable polymorphic loci between the two parental lines (Fig. 1). With seven primer pairs, a total of 57 polymorphic loci that were reproducible and did not significantly deviate from a 1:1 segregation ratio were mapped in the $\mathrm{DH}$ lines. In addition, 40 out of 98 total RGA restriction fragment length polymorphism (RFLP) probes from rice, barley, and maize detected 46 polymorphic loci whereas 11 out of 138 total DR gene probes detected 15 polymorphic loci. Together with the anchor markers, a total of 302 markers were placed on the map (Fig. 1, Table 1).

The relative amount of polymorphism detected by different RGA and DR gene probes was compared (Table 2). When RGAs were used as RFLP probes, over $40 \%$ of the enzymegene combinations were polymorphic between IR64 and Azucena. The rice NBS-LRR sequences detected less polymorphism $(37.8 \%)$ than those from barley and maize $(75.0 \%)$. The DR gene sequences used detected much less polymorphism $(<12 \%)$ regardless of the source of probes. Several of the RGA probes detected multiple loci (e.g., the $R p 1$ probe detected five different segregating loci). Although most of the DR gene probes detected no polymorphism or a single locus, a few detected multiple loci. The exceptions were the dihydrofolate reductase thymidylate synthase (ZmDRT) and thaumatin (PR5), which detected four loci on chromosomes 11 and 12 and two loci on chromosomes 6 and 7 , respectively.

\section{Location of candidate gene markers and degree of clustering.}

A total of $116 \mathrm{DH}$ lines were used to determine association of candidate gene markers with qualitative and quantitative resistance. Of 46 NBS-LRR marker loci mapped on the DH population, 12 are located on chromosome 11. Clustering of NBS-LRR genes mapped on rice chromosome 11 was previ- 

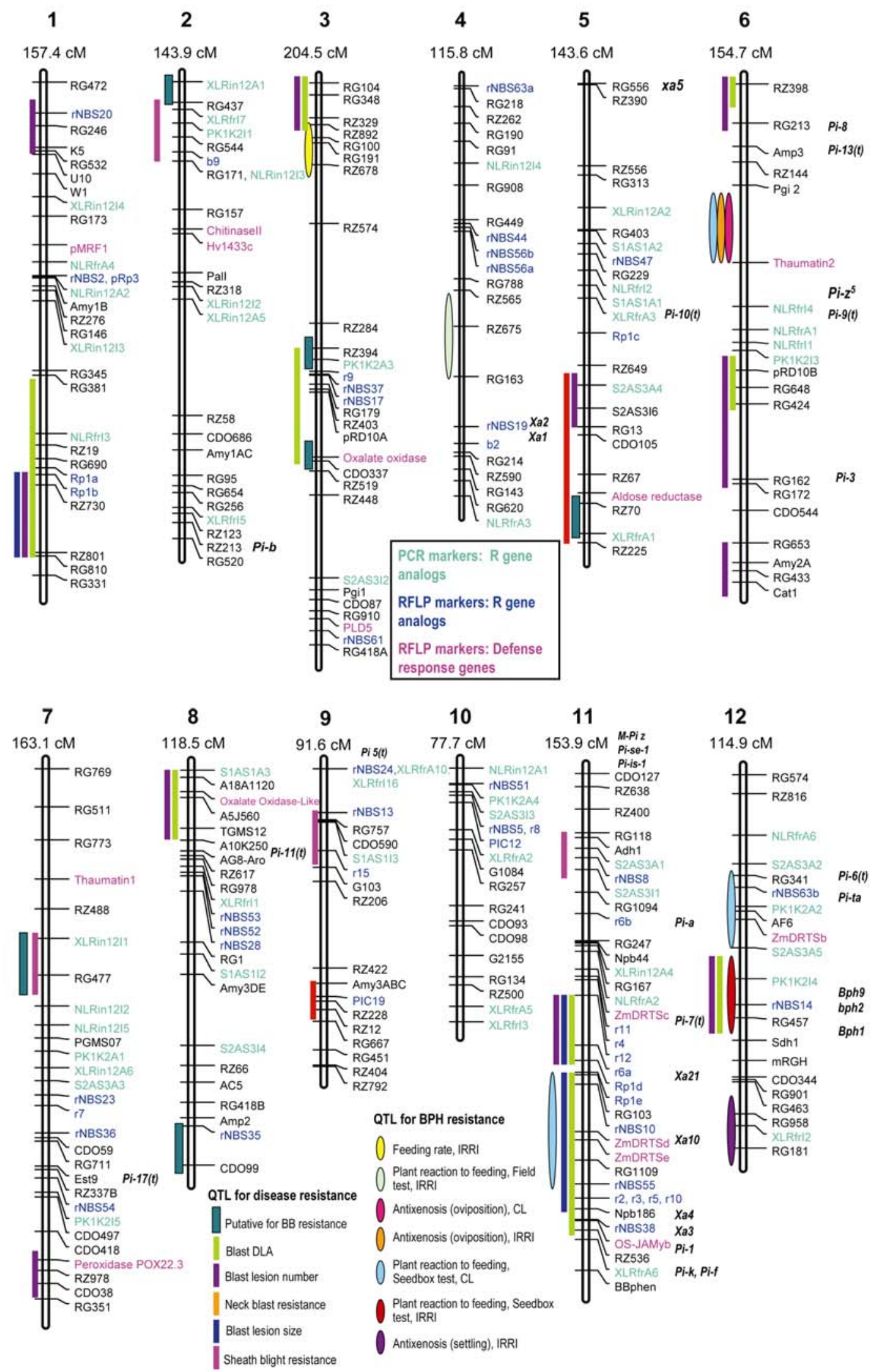

Fig. 1. Map of doubled haploid lines (IR64 and Azucena) showing 118 candidate gene loci (i.e., 57 polymerase chain reaction [PCR]-based resistance gene analogs, 46 restriction fragment length polymorphism [RFLP]-based resistance gene analogs, and 15 RFLP-based defense response genes). Map positions of quantitative trait loci (QTL) for blast (Prashanth et al. 1998; Wang et al. 1994) and sheath blight (Zou et al. 2000) were inferred from published data. Brown planthopper (BPH) QTL in chromosomes 3, 4, and 6 detected by Alam and Cohen (1998) were confirmed in this study. The positions of all bacterial blight (BB) and BPH QTL were derived using Qgene (Nelson 1997). BB ( $\log _{10}$ likelihood ratio [LOD] $\geq 1.8$ ) and BPH QTL (LOD $\left.\geq 2.4\right)$ positions were determined in this study. BB QTL were based on lesion length. The resistance R genes $(\mathrm{Xa}, \mathrm{Pi}$-, or $\mathrm{Bph})$ were positioned relative to the closest referenced anchor marker obtained from published literature (Huang et al 1997, Leister et al 1999, Wang et al 1994, Yoshimura et al. 1996). 
ously observed by Leister and associates (1998). Within chromosome 11, the rice NBS-LRR sequences (rNBS 8, 10, 38, 55, $\mathrm{r} 2, \mathrm{r} 3, \mathrm{r} 4, \mathrm{r} 5, \mathrm{r} 6, \mathrm{r} 10, \mathrm{r} 11$, and $\mathrm{r} 12$ ) clustered to three regions that span the $112.5 \mathrm{cM}$ estimated between markers rNBS8 and rNBS38: region $1=$ rNBS8 to $12(42.6 \mathrm{cM})$, region $2=$ r6a to rNBS10 $(12.3 \mathrm{cM})$, and region $3=$ rNBS55 to $\operatorname{rNBS} 38$ (11.9 $\mathrm{cM})$. In addition, two of five loci detected by the maize $R p l$ gene probe map to this region. Other loci detected by the $R p 1$ probe map to chromosomes 1 and 5. Loci detected by maize RGA clones (PIC12, pRP3, and PIC19) also are distributed throughout the chromosomes. Of all the barley clones tested, only two NBSLRR probes, b2 and b9, detected polymorphism and these mapped to chromosomes 4 and 2, respectively.

Some probes detected polymorphisms that mapped to the same genetic locus (i.e. no recombination) even though they did not cross hybridize. Such clusters also were observed by Leister and associates (1998) and were designated mixed R gene homolog clusters (RHCs). In this case, rNBS2 and pRp3 on chromosome 1, rNBS5 and r8 on chromosome 10 , and $\mathrm{r} 2$, r3, r5, and r10 on chromosome 11 mapped as a single locus.

Compared with the NBS-LRR sequences, the PCR-derived markers are more evenly distributed over the chromosomes. However, within each chromosome, the PCR-based markers also tended to cluster, and some were associated with the NBSLRR sequences. This is not surprising because a majority of the PCR markers are amplified using primers designed from the conserved regions of NBS and LRR sequences. Not all clusters defined by PCR markers were associated with NBSLRR probes. For example, there were three clusters of PCR markers on chromosome 2 but only one NBS-LRR locus, b9, was located in the neighboring region. As more NBS-LRR sequences become available, it should be possible to confirm if the PCR markers coincide with NBS-LRR sequences on the map. Clusters of NBS-LRR sequences, notably on chromosome 11, were associated with a number of major genes and QTL for blast, BB, BPH, and sheath blight. This could be a reflection of the relative high abundance of NBS-LRR sequences in rice in this region (Bai et al. 2002).

A total of 138 DR genes representing genes involved in different defense pathways were hybridized against parental DNA cut with six different restriction enzymes, but only 11 genes showed polymorphism. Most of the mapped DR genes detected single loci with variable copy number and mapped on different chromosomes. Thus, although the numbers were small, in general, DR genes were randomly distributed among and within chromosomes and did not cluster as was observed for the NBS-LRR or PCR markers.

\section{Association with major $\mathbf{R}$ genes.}

A large number of major $\mathrm{R}$ genes conferring resistance to $\mathrm{BB}$ ( $\mathrm{X} a$ genes) and blast ( $P i$ genes) have been located previously in different rice mapping populations. Of the 10 markers linked to R genes reported by Leister and associates (1999), 8 are on chromosome 11, which carries many known $\mathrm{R}$ genes (Pi-1, Pi-k, Pi-f, Pi-7(t), XalO, Xa3, and Xa4). In this study, including the probes reported by Leister and associates (1999), we placed 20 RGA markers on chromosome 11 in the $\mathrm{DH}$ lines; several were associated with positions of known $\mathrm{R}$ genes. For example, the r11-r4-r12 region is associated with $P i-7(t)$, and the r10-r2-r5-r3, rNBS38, and XLRfrZ6 regions are associated with $\mathrm{Xa} 4 \mathrm{Xa3}$, and $\mathrm{Pi}-1$.

\section{Allelic contribution of QTL.}

Using two Xanthomonas oryzae pv. oryzae strains (PXO79 and PXO86) that are virulent to IR64 and Azucena, we identified six chromosomal regions with significant BB QTL based on single-point analysis $(P \leq 0.01)$. The putative QTL mapped to five different chromosomes (2, 3, 5, 7, and 8) (Table 3). These QTL were estimated to explain from 8.4 to $14.3 \%$ of the total variation in lesion length. The region on chromosome 5, flanked by the XLRfrA1 and RZ70, showed the most statistically significant QTL with a $\log _{10}$ likelihood ratio (LOD) score of 3.1 (Table 3). Progeny lines carrying the IR64 parent genotypes for this interval had average lesion lengths of $24.1 \mathrm{~cm}$ after inoculation with PXO86, whereas those with the Azucena parent genotype had average lesion lengths that were approximately $3.2 \mathrm{~cm}$ shorter. The locus showed no significant effect on resistance to isolate PXO79, however, because the progeny lines with the IR64 alleles are not significantly different from those with the Azucena alleles. Similarly, the other QTL with lower LOD scores showed significant difference between lesion lengths with PXO86 $(P \leq 0.05)$ but not PXO79 (Table 3 ). The lack of significant effects of the QTL on inoculations with PXO79 suggests their effects are race specific. However, there

Table 1. Candidate genes used in this study: clone designation, plant source, and predicted function or pathway

\begin{tabular}{|c|c|c|c|c|}
\hline Gene categories & Accession number & Clone designation & Predicted function or pathway & Source \\
\hline \multirow[t]{2}{*}{ NBS-LRR } & AF032688-AF032702 & r1-r15 & Resistance gene analog & Rice \\
\hline & $\ldots$ & rNBS1-rNBS69 ${ }^{\mathrm{b}}$ & $\ldots$ & $\ldots$ \\
\hline \multirow[t]{3}{*}{ NBS-LRR } & AF032680 & $\mathrm{b} 2$ & Resistance gene analog & Barley \\
\hline & AF032683 & b5 & $\ldots$ & $\ldots$ \\
\hline & AF032687 & b9 & $\ldots$ & $\ldots$ \\
\hline \multirow[t]{2}{*}{ NBS-LRR } & AF056152 & PIC12 & Resistance gene analog & Maize \\
\hline & AF056159 & PIC19 & $\ldots$ & $\ldots$ \\
\hline Rpl & AF107293 & Rp1-D & $R p 1-D$ rust resistance gene & Maize \\
\hline Rp3 & AF489541 & $\mathrm{pRp} 3^{\mathrm{c}}$ & $R p 3$ rust resistance gene family member & Maize \\
\hline Peroxidase & AF014467 & $\mathrm{POX} 22.3$ & Multiple & Rice \\
\hline Aldose reductase & X57526 & $\operatorname{pg} 2269$ & Phenylpropanoid pathway & Barley \\
\hline Dihydrofolate reductase thymidylate synthase & AF073488 & ZmDRTS & Amino acid metabolism & Maize \\
\hline S-adenosyl methionine synthetase (SAM) & Z26867 & pMRF1 & Amino acid metabolism & Rice \\
\hline Oxalate oxidase & Y14203 & PHvOXOa & Generation of active oxygen species & Barley \\
\hline Oxalate oxidase-like protein & X93171 & pBH6-903 & Generation of active oxygen species & Barley \\
\hline Hv1433c & Y14200 & pHv1433c & PR Protein & Barley \\
\hline Chitinase TypeII & X78671 & $\mathrm{HvCht} 2 \mathrm{a}$ & PR Protein & Barley \\
\hline Phospholipase D & AF271358 & PLD5 & Lipid modification & Rice \\
\hline PR5 Thaumatin & BH72-C6 & $\mathrm{pBH72-C6}$ & PR Protein & Barley \\
\hline$J A M y b$ & AY026332 & OS-JAMyb & Jasmonic acid pathway & Rice \\
\hline
\end{tabular}

${ }^{a}$ A complete list of these clones and their sources can be found at the Kansas State University Defense Gene Collection website.

b Bai et al. 2002 .

c A subclone that contains 1,052 bp of the nucleotide binding site region of a $R p 3$ family member. 
is a trend toward shorter lesions in plants carrying the Azucena alleles at all six loci, even in the PXO79 inoculations. For example, progeny lines carrying the Azucena allele at the putative QTL on chromosome 8 had lesion lengths $3.23 \mathrm{~cm}$ shorter than the progeny with the IR64 alleles after inoculation with isolate PXO86 $(P \leq 0.01)$. When inoculated with isolate PXO79, the lines with the Azucena allele at this locus were $2.95 \mathrm{~cm}$ shorter, though the difference was not significant. It is possible that these QTL are more effective against isolate PXO86 than PXO79. More likely, however, the high variation in lesion lengths observed after inoculation with PXO79 resulted in the inability to detect small differences in resistance caused by the QTL.

Considering all QTL together, evidence of transgressive segregation was observed in the $\mathrm{DH}$ progeny (Fig. 2). For example, DH line 455, with Azucena alleles on all six BB QTL regions, was significantly more resistant than both parents to $X$. oryzae pv. oryzae isolates PXO86 $(6.1 \mathrm{~cm}$ lesion lengths versus $19.2 \mathrm{~cm}$ for Azucena and $19.4 \mathrm{~cm}$ for IR64) and PXO79 (5.7 $\mathrm{cm}$ for line 455 versus $18.8 \mathrm{~cm}$ for Azucena and $19.0 \mathrm{~cm}$ for IR64) $(P \leq 0.0001)$. On the other hand, DH line 303, with IR64 parental alleles at six BB QTL regions, was significantly more susceptible than both parents to PXO86 (30.6 cm for line $303,17.3 \mathrm{~cm}$ for IR64, $19.2 \mathrm{~cm}$ for Azucena) and PXO79 (25.5 $\mathrm{cm}, 19.1 \mathrm{~cm}$ for IR64, $18.8 \mathrm{~cm}$ for Azucena) $(P \leq 0.0001)$. The observation of transgressive segregation is especially interesting because the Azucena parent contributed the resistant allele at all six predicted QTL, but Azucena was not significantly more resistant to either BB isolate than IR64. Apparently, other genomic regions in Azucena may carry alleles with negative effects that reduce the level of resistance in the original Azucena genotype; this condition was detected by both phenotypic and QTL analyses. Our inability to detect these loci may be due either to their small effects or possibly to genetic interactions (e.g., epistasis) between the different loci that affect their expression.

Using 109 additional candidate gene markers, we have confirmed the locations of five of the QTL for BPH resistance previously identified by Alam and Cohen (1998) in a study using the same DH population with 175 RFLP and isozyme markers. In addition, we placed four QTL to new chromosomal regions. We identified three putative QTL for BPH resistance on chromosome 6, three on chromosome 12 and one each on chromosomes 3, 4, and 11 with LOD scores higher than 2.4 (Table 4). All resistance alleles were derived from the IR64 parent except the one on chromosome 4. The identification of the additional QTL in this study is likely due to the increased genome coverage with additional new markers used in this analysis. For example, Alam and Cohen (1998) detected no QTL on chromosome 12 by using 11 markers. However, with the addition of nine candidate genes to the region, we detected three QTL for BPH resistance with LOD values of 2.5 to 4.5. Four QTL identified by Alam and Cohen (1998) were not identified in the present study, presumably because of the smaller number of lines and the higher-threshold LOD values used in our analysis. Furthermore, Alam and Cohen (1998) used MLE in Mapmaker/QTL whereas the present study applied regression analysis in QGene (v2.26) for QTL detection.

\section{Association of candidate genes with QTL.}

Of the six BB QTL identified in this study, one region in chromosome 3 was associated with a putative candidate gene based on a simple regression analysis $(P=0.01)$. On chromosome 3, qBB3-2, a short BB QTL region accounting for $10.3 \%$ phenotypic variation, is closely associated with oxalate oxidase; a portion of the same chromosomal region is associated with a blast QTL defined by percent disease leaf area. However, when a permutation test was conducted to determine the appropriate threshold, the association of qBB3-2 with oxalate oxidase was not significant. Nonetheless, in other mapping populations, oxalate oxidase is found to provide a high level of quantitative resistance to fungal pathogens of wheat (Faris et al. 1999) and rice (L. Bin and H. Leung, unpublished data). The low or nonsignificant phenotypic effect of oxalate oxidase observed in the DH mapping population may reflect an inherently lower level of quantitative resistance conferred by the specific allele in Azucena against the bacterial blight pathogen.

The putative QTL for BPH antixenosis (oviposition) on chromosome 6 was flanked by thaumatin 2 and Pgi2. Three putative BPH QTL were identified on chromosome 12, one being associated with dihydrofolate reductase thymidylate synthase (ZmDRTSb). A BPH QTL located on chromosome 11 also was associated with two ZmDRTS genes (ZmDRTSd and ZmDRTSe). Both of the putative QTL that are associated with ZmDRTS genes relate to the same trait for $\mathrm{BPH}$ resistance (i.e., plant reaction to $\mathrm{BPH}$ feeding).

In addition to using the experimental data we obtained for $\mathrm{BB}$ and $\mathrm{BPH}$, published maps and QTL results in the literature were surveyed to identify association between candidate gene markers with QTL responsible for blast and sheath blight. Based on two QTL studies on blast resistance (Prashanth et al. 1998; Wang et al. 1994), a total of 24 QTL have been mapped (Fig. 1.). Similarly, four sheath blight QTL previously placed on the chromosomal map (Zou et al. 2000) were linked with candidate genes. The DR genes oxalate oxidase, aldose reductase, peroxidase, $J A M y b$, and dihydrofolate reductase thymidylate synthase are associated with blast QTL. Some DR genes are associated with more than one resistance QTL. For example, oxalate oxidase on chromosome 3 is associated with BB and blast resistance and dihydrofolate reductase thymidylate

Table 2. Polymorphism and number of loci detected in restriction fragment length polymorphism (RFLP) analysis of IR64 and Azucena using probes of resistance gene analogs (NBS-LRR) and defense response candidate genes

\begin{tabular}{|c|c|c|c|c|}
\hline \multicolumn{2}{|c|}{ RFLP probe } & \multirow[b]{2}{*}{ Percent polymorphism ${ }^{a}$} & \multirow[b]{2}{*}{ No. loci mapped } & \multirow[b]{2}{*}{ Percent total loci mapped } \\
\hline Category, source & Number & & & \\
\hline \multicolumn{5}{|c|}{ Resistance gene analogs } \\
\hline Rice & 90 & 37.8 & 37 & 12.6 \\
\hline Non-rice & 8 & 75.0 & 9 & 3.1 \\
\hline Total & 98 & 40.8 & 46 & 15.7 \\
\hline \multicolumn{5}{|c|}{ Defense response gene } \\
\hline Rice & 25 & 12.0 & 3 & 1.0 \\
\hline Non-rice & 113 & 7.1 & 12 & 4.1 \\
\hline Total & 138 & 7.9 & 15 & 5.1 \\
\hline
\end{tabular}

${ }^{a}$ Polymorphism detected per probe enzyme combinations; six restriction enzymes were tested. Percent polymorphism detected $=($ number of polymorphic probes/total number of probes surveyed) $\times 100$.

${ }^{\mathrm{b}}$ Percent total loci mapped $=($ number of loci mapped/total number of markers mapped $) \times 100$. 
synthase is linked with QTL of BPH and blast on chromosomes 11 and 12, respectively. Interestingly, the PIC19 gene, a maize NBS-LRR gene which maps near several disease resistance genes in maize (Collins et al. 1998), is associated with a region $(11.9 \mathrm{cM})$ on chromosome 9 that shows effect against neck blast. Of particular interest are the common chromosomal regions associated with different resistances, such as $\mathrm{BB}$ and sheath blight on chromosomes 2 and 7; blast and $\mathrm{BPH}$ on chromosomes 3,11 , and 12; and blast and BB on chromosomes 3 and 5.

\section{Maize-rice synteny in regions carrying $R$ genes.}

We used the map positions of six NBS-LRR sequences from maize to estimate how frequently these genes reside on linkage blocks that are conserved within rice and maize. $R p 1$ maps to a single complex locus on the short arm of maize chromosome 10. A probe comprising the $5^{\prime}$ half of the $R p l$ gene also identifies a gene family in rice. Interestingly, the family maps to three different locations in rice. The probe identified two linked loci on chromosome 1 (2.4 cM apart), a single locus on chromosome 5, and a pair of linked loci on chromosome 11 (3.9 cM apart). The PIC19 probe identified an NBS-LRR gene family in maize that maps near a cluster of resistance genes (Collins et al. 1998) that are closely linked to the nucleolus organizer (NOR) on maize chromosome 6. In rice, this maps to chromosome 9 which also carries one of the two rice NOR. It is doubtful, however, that this represents a conserved linkage arrangement, because the rice locus is on the opposite arm of rice chromosome 9, as is the NOR. Furthermore, the marker closest to the rice PIC19 homologous locus that has been mapped in maize is RZ422. RZ422 maps $9 \mathrm{cM}$ above PIC19 in rice but maps to maize chromosome 7 (Ahn and Tanksley 1993). The PIC12 marker maps to the top (short arm) of rice chromosome 10 above G1084 and RG257. PIC12 maps on maize chromosome 1 near the rice markers RZ421 and RZ500. RZ500 also maps to rice chromosome 10, but on the long arm near the opposite end of the chromosome.

The pRp3 marker is thought to code for a member of the $R p 3$ rust resistance gene family of maize (Collins et al. 1998) that maps to chromosome 3 of maize (Webb et al. in press). The homologous locus maps near the centromere of rice chromosome 1 , within $1.2 \mathrm{cM}$ of Amy1B. This region, between Amy1B and RZ995, corresponds to a syntenic region of maize chromosome 3 (Ahn and Tanksley 1993). Genes controlling resistance to Maize mosaic virus, Wheat streak virus, and Sugarcane mosaic virus and genes contributing quantitative levels of resistance to
European corn borer and Fusarium stalk rot also have been mapped near this region in maize (McMullen and Simcox 1995; Ming et al. 1997; Xu et al. 1999). The region is not completely syntenic with rice, however, because the $\mathrm{mRGH}$ and CDO344 markers map approximately 1 and 3 to $5 \mathrm{cM}$ towards the centromere of chromosome 3 from $\mathrm{pRp} 3$, respectively, in maize but map at $5.3 \mathrm{cM}$ apart on chromosome 12 in rice. These loci on maize chromosome 3 and rice chromosomes 1 and 12 appear to represent some syntenic chromosome regions, but rearrangements or duplications also are apparent.

\section{DISCUSSION}

Candidate genes, which included recognition and general defense genes, were associated with map positions for resistance for both minor and major genes to rice blast, BB, sheath blight, and BPH. The candidate genes added 118 marker loci to a widely used, existing RFLP map of a rice DH population. IR64 also is widely used in mutational analysis (Leung et al. 2001) and as parent for many breeding programs; therefore, the candidate gene markers generated for the map will provide a useful framework for allele identification in mutants and advanced breeding populations.

Six DR genes, including oxalate oxidase (accession numbers Y14203, X93171), aldose reductase (X57526), peroxidase (AF014467), dihydrofolate reductase thymidylate synthase (AF073488), and JAMyb (AY026332), map within blast QTL. One DR gene, oxalate oxidase (accession number Y14203) maps within a BB resistance QTL, although the association was not significant in a permutation test. Several lines of evidence implicate these genes as contributing to quantitative and broad-spectrum resistance to pathogens. Aldose reductase has been implicated in detoxification of fungal toxins (Colrat et al. 1999; Meeley et al. 1992) and in desiccation tolerance of mature seed in barley (Bartels et al. 1991) and vegetative tissues in oat ( $\mathrm{Li}$ and Foley 1995). Oxalate oxidase and peroxidase are involved in production of active oxygen species, which may play various roles in reduction of pathogen viability and spread (Lamb and Dixon 1997; Mehdy 1994; Tenhaken et al. 1995). Induction of oxalate oxidase and peroxidase gene expression is correlated with defense responses. Oxalate oxidase is induced in barley seedlings in response to attack by the powdery mildew fungus (Dumas et al. 1995; Nicholson and Hammerschmidt 1992; Zhang et al. 1995; Zhou et al. 1998). Expression of wheat germin oxalate oxidase in transgenic poplar leaves confers resistance to Septoria musiva, a fungal

Table 3. Candidate genes associated with chromosome regions containing quantitative trait loci (QTL) effect against bacterial blight

\begin{tabular}{|c|c|c|c|c|c|c|c|c|c|}
\hline \multirow[b]{3}{*}{ QTL $^{\mathbf{b}}$} & \multirow[b]{3}{*}{ Chromosome interval $^{\mathrm{c}}$} & \multirow[b]{3}{*}{$F_{\mathrm{c}}^{\mathrm{d}}$} & \multirow[b]{3}{*}{$R^{2}(\%)^{\mathrm{e}}$} & \multirow[b]{3}{*}{$P^{f}$} & \multirow[b]{3}{*}{ LOD $^{g}$} & \multicolumn{4}{|c|}{ Mean lesion length for genotype ${ }^{a}$} \\
\hline & & & & & & \multicolumn{2}{|c|}{ PXO86 } & \multicolumn{2}{|c|}{ PXO79 } \\
\hline & & & & & & IR64 & Azucena & IR64 & Azucena \\
\hline qBB2 & XLRin12A1 RG437 & 7.4 & 8.4 & 0.008 & 2.1 & 23.7 & $20.8^{* *}$ & 21.8 & $20.4^{\mathrm{ns}}$ \\
\hline qBB3-1 & PK1K2A3 RZ394 & 9.2 & 9.9 & 0.003 & 2.0 & 23.4 & $19.9 * *$ & 22.2 & $19.7^{\mathrm{ns}}$ \\
\hline qBB3-2 $2^{\mathrm{h}}$ & CDO337 Oxalate oxidase & 7.7 & 10.3 & 0.007 & 1.8 & 23.2 & $20.8^{* *}$ & 21.7 & $20.2^{\mathrm{ns}}$ \\
\hline qBB5 & XLRfrA1 RZ70 & 12.1 & 12.9 & 0.0008 & 3.1 & 24.1 & $20.9^{*}$ & 22.4 & $20.2^{\mathrm{ns}}$ \\
\hline qBB7 & RG477 NLRin12I2 & 10.9 & 14.3 & 0.002 & 2.6 & 23.2 & $19.5 * *$ & 21.6 & $19.9^{\mathrm{ns}}$ \\
\hline qBB8 & rNBS35 CDO99 & 10.3 & 11.4 & 0.002 & 2.2 & 22.9 & $19.7 * *$ & 21.8 & $18.9^{\mathrm{ns}}$ \\
\hline
\end{tabular}

${ }^{a}$ Means of lesion length of all doubled haploid lines carrying IR64 and Azucena alleles are significantly different from each other at $\mathrm{P} \leq 0.01$ ( $* *$ ) or $P \leq$ $0.05(*)$ for PXO86; ns = not significant.

${ }^{\mathrm{b}}$ QTL are named based on McCouch and associates (1997).

${ }^{\mathrm{c}}$ Markers defining QTL, where the first named marker in the interval is the most significant in single-point linkage tests.

${ }^{\mathrm{d}} F_{\mathrm{c}}=$ regression mean square/error mean square.

${ }^{\mathrm{e}} R^{2}=$ regression sum of square/total sum of square, phenotypic variance explained by the QTL.

${ }^{\mathrm{f}} P$ (probability) is the level of significance when the computed $F$ value is compared to the tabular $F$ value.

${ }^{\mathrm{g}} \mathrm{LOD}=\log _{10}$ of odds ratio.

${ }^{\mathrm{h}}$ Based on simple regression analysis, $\mathrm{qBB} 3-2$ is associated with the oxalate oxidase marker $(P=0.01)$. However, based on a permutation test $(P=0.05)$, qBB3-2 defined by the CDO337 and oxalate oxidase interval is not significant. 
pathogen that produces oxalic acid (Liang et al. 2001). In rice, induction of specific peroxidases is correlated with resistance to BB (Chittoor et al. 1997; Hilaire et al. 2001). Although not directly linked with DRs, expression of the gene encoding the bifunctional dihydrofolate reductase thymidylate synthase that correlates with blast and BPH QTL is enhanced and enzyme activity specific to cells where DNA synthesis is active (Cox et al. 1999; Vandiver and Fites 1979).

Growing evidence suggests that there are shared plant defense pathways and defense proteins for responses to pathogens and insects, and that the similarities between plant responses to pathogens and insects are most extensive in the case of phloem-feeding insects such as aphids and whiteflies (Walling 2000). Plant-hoppers also are principally phloem feeders, but no molecular-level studies examining the response of plants to these insects have yet been published. Genes induced by aphid and whitefly feeding that also are known to be induced by pathogens include those encoding glucanases, lipoxygenases, peroxidases, phenyalanine ammonia lyase, PDF1.2 (defensin), and PR-1 (Ochman et al. 1999; Walling 2000). The candidate genes used in our study included a peroxidase and a chitinase, though neither co-localized with QTL for BPH resistance. Nonetheless, the association of other candidate gene markers with QTL allows us to pose additional hypotheses to evaluate the role of known genes in insect resistance. For example, PR5 (Pierpoint et al. 1990) encodes a thaumatin-like protein and is associated with a QTL for antixenosis to oviposition by BPH populations obtained from IRRI farm and Central Luzon. The QTL linked with thaumatin had phenotypic variance of more than $16.0 \%$ and an LOD score of 2.4. The thaumatin-like protein has a sequence similar to that
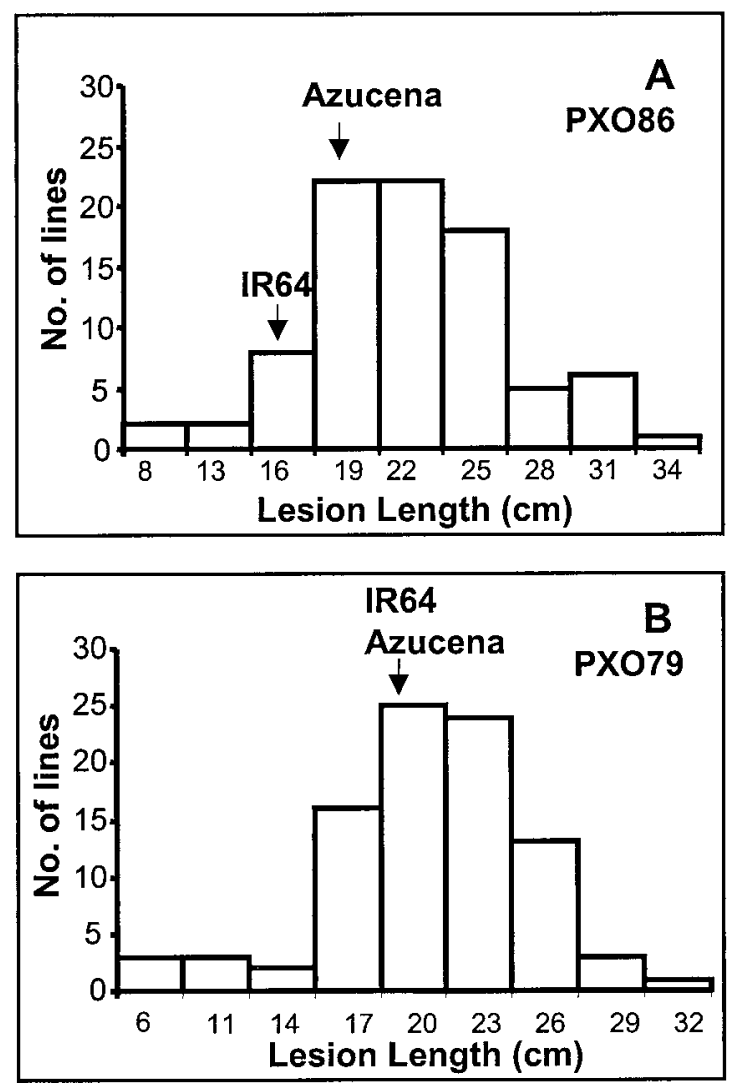

Fig. 2. Frequency distribution of lesion length $(\mathrm{cm})$ for bacterial blight (BB) resistance against Xanthomonas oryzae pv. oryzae isolates A, PXO86 and B, PXO79 in the doubled haploid lines of the cross IR64 $\times$ Azucena. Arrows indicate the mean values of the parental cvs. IR64 and Azucena. of thaumatin, a sweet tasting protein from Thamatococcus danielli (Pierpoint et al. 1990; van der Wel and Loeve 1972). Members of this group exhibit antifungal activity against a broad spectrum of fungal pathogens (Malehorn et al. 1994; Vigers et al. 1992; Woloshuk et al. 1991). In rice, these proteins are induced after infection with the sheath blight fungus Rhizoctonia solani and are encoded by three genes that are differentially expressed in responses to bacterial or fungal pathogens (Velazhahan et al. 1998). Mapping of additional candidate genes that are known to be associated with plant responses to sucking insects onto the IR64-Azucena map should help to generate further hypotheses concerning genes associated with QTL for BPH resistance.

In the present study, most of the RGAs (except r6, Rpl, rNBS56, and rNBS63), and DR genes (except dihydrofolate reductase thymidylate synthase and thaumatin) detected single loci with variable copy number and mapped on different chromosomes. Clusters of NBS-LRR sequences were observed most notably on chromosome 11 , where many known blast and BB R genes and QTL for blast, BB, sheath blight, and BPH are located. If these NBS-LRR genes represent candidates of functional resistance genes, they should exhibit linkage to characterized resistance loci. Though these recognition-type $\mathrm{R}$ genes are most commonly associated with controlling high levels of resistance, there is evidence suggesting that some also are associated with quantitative resistance (Koch and Parlevliet 1991; Martin and Ellingboe 1976; Nelson 1972). Many of these $\mathrm{R}$ genes are in complex loci, and carry multiple homologous genes (Ellis and Jones 1998; Ronald 1998). Mapping studies have shown that some putative QTL are localized in chromosomal regions that harbor these $\mathrm{R}$ genes (McMullen and Simcox 1995; Wang et al. 1994), although it has not been determined whether any QTL are R gene family members. The map presented in this study provides the framework to test this hypothesis.

Some rice NBS-LRR clones identified as independent loci in other populations were mapped to the same location (e.g., r2, $\mathrm{r} 3, \mathrm{r} 5$, and r10) using the DH lines. This could be due to the limited recombination in the $\mathrm{DH}$ population, because the $\mathrm{DH}$ lines were brought to a homozygous state after one meiosis. The limited recombination and relatively small size of our population could pose limitations for fine mapping. Nonetheless, the localization of candidate gene sequences in a wellmarked chromosomal region will enable to us to compare functionality of the loci in different mapping and breeding populations. Indeed, several candidate genes (e.g., oxalate oxidase and PR proteins) have been demonstrated to contribute partial resistance against rice blast in a backcross breeding program (Liu Bin and H. Leung, unpublished data).

An important benefit of candidate resistance gene approach is to associate function to genes across species based on syntenic relationship and sequence conservation. Good syntenic relationship in NBS-LRR homologs has been observed between tomato and potato (Pan et al. 2000). However, the syntenic relationships when comparing the NBS-LRR sequences in rice, barley, and foxtail millet were not as clear as those observed with other markers in the grass genomes, leading to the hypothesis that resistance gene-like sequences undergo rapid divergence and reorganization (Devos and Gale 2000; Leister et al. 1998). In this study, we also saw no obvious syntenic relationships between maize and rice using these markers. More species comparison is needed to determine whether NBS-LRR sequences are unique in the way they evolve in the genome. Regardless of syntenic relationship, the conserved sequences allowed us to apply the NBS-LRR sequences from maize and barley to rice. Therefore, unlike the use of anonymous DNA, the use of candidate genes with suffi- 
cient sequence similarity is, to a large extent, independent of their chromosomal locations.

Our work indicates that the candidate gene approach can be an efficient way to establish, at least on a coarse scale, the association between candidate genes and functionality. Several candidate gene markers were associated with qualitative and quantitative resistance for disease and an insect. If these genes themselves are involved in resistance, they will be useful for marker-assisted selection breeding programs. However, to determine the generality of this approach, more candidate gene markers need to be placed on the map generated by populations segregating for the traits of interest. This will allow a more precise estimate of the association the candidate gene markers and the phenotypes. The recent publication of the draft rice genome sequences (Goff et al. 2002; Yu et al. 2002) will accelerate the identification of gene function using the candidate gene approach.

\section{MATERIALS AND METHODS}

\section{Plant material and DNA extraction.}

DH lines (116) of a cross between IR64 and Azucena (Guiderdoni et al. 1992) were provided by Plant Breeding, Genetics and Biochemistry Division, International Rice Research Institute (IRRI), Manila, The Philippines. IR64 carries Xa4 and is resistant to many strains of the $\mathrm{BB}$ pathogen $(X$. oryzae pv. oryzae), blast pathogen (Magnaporthe grisea), and the insect BPH (Nilaparvata lugens [Stal]), whereas Azucena is generally susceptible. The DH population segregates for BB, blast, and $\mathrm{BPH}$ resistance. Leaves of rice plants grown in a greenhouse were harvested for DNA extraction at 21 days. Leaves were ground in liquid nitrogen, and genomic DNA was extracted using a modified hexadecetyltrimethylammonium bromide procedure (Saghai-Maroof et al. 1984).

\section{Phenotypic evaluation of QTL.}

To obtain segregation data for $\mathrm{BB}, \mathrm{DH}$ lines were inoculated with suspension of $X$. oryzae pv. oryzae PXO86 (race 2) or PXO79 (race 3 ) by the leaf clipping method at maximum tillering stage as described (Kauffman et al. 1973). Both PXO86 and PXO79 are virulent to IR64, which contains the Xa4 BB resistance gene; both strains also cause disease on Azucena. Each strain-line combination was replicated two times, with two plants per replicate in a split-plot design with strains as a main plot and DH lines as the subplot. Lesion lengths for BB were scored at 14 days after inoculation and the mean lesion length of each line was used in QTL analysis. Means of lesion length for the lines were obtained from two replications each of PXO86 and PXO79 inoculations. Comparison of mean lesion lengths for each isolate was based on analyses using the mixed procedure and $t$ test of SAS (version 8.2; SAS Institute Inc., Cary, NC, U.S.A.).

The BPH screening methods were described (Alam and Cohen 1998). These authors scored seven resistance traits in the IR64-Azucena DH population using two populations of BPH from Luzon Island, The Philippines. The traits included antixenosis (a plant quality that repels or disturbs insects, causing a reduction in colonization or oviposition), feeding rate, and phenotypic tests that measures plant reaction to $\mathrm{BPH}$ feeding in a seedbox or in the field. In the present article, the phenotypic data of Alam and Cohen (1998) are reanalyzed using the additional candidate gene markers.

\section{RFLP and PCR analyses.}

The clones used for RFLP analysis (from the Kansas State University defense gene collection) include contributions from different researchers and were either reported to be involved in plant defense responses or are known resistance genes. Each clone was verified by restriction analysis after receipt. After transformation into Escherichia coli, clones were catalogued and stored at $-80^{\circ} \mathrm{C}$. The clones used to construct the map in the present study, their sources, and the putative pathway in which they are involved are indicated in Table 1. Probes for hybridization were prepared by restriction enzyme digestion and purification of the relevant fragment or by PCR amplification.

RGA clones were obtained by amplifying the NBS containing sequences from rice and maize DNA (Bai et al. 2002). Oligonucleotide primers were designed based on the conserved motifs in the aligned amino acid sequences derived from known NBS-containing genes. Forward primers were designed to correspond to the P-loop motif and reverse primers were made corresponding to a few conserved amino acids (MHD) at the end of the NBS region to amplify approximately $900 \mathrm{bp}$. The PCR amplification was performed in $50 \mu \mathrm{l}$ of reaction volume containing 200 to $250 \mathrm{ng}$ of genomic DNA from either rice $\mathrm{cv}$. Nipponbare or maize inbred line B73. PCR products were separated on a $1.0 \%$ agarose gel and DNA fragments of 0.9 to $1.0 \mathrm{~kb}$ in size were extracted and cloned in

Table 4. Quantitative trait loci (QTL) associated with brown plant-hopper (BPH) resistance identified in the doubled haploid (DH) population

\begin{tabular}{|c|c|c|c|c|c|c|c|}
\hline QTL $^{\mathbf{a}}$ & Chromosome interval $^{\text {b }}$ & Trait/test site ${ }^{c}$ & $F_{\mathrm{c}}^{\mathrm{d}}$ & $R^{2}(\%)^{\mathrm{e}}$ & $P^{f}$ & LOD $^{g}$ & Additive $^{\mathrm{h}}$ \\
\hline $\mathrm{qBPH}^{\mathrm{i}}$ & RG191-RZ678 & Feeding rate/IRRI & 17.8 & 17.5 & 0.0001 & 3.9 & -4.28 \\
\hline qBPH4 & RZ675-RG163 & Plant reaction to feeding/Field, IRRI & 12.9 & 16.7 & 0.0006 & 2.5 & 0.61 \\
\hline qBPH6-1 & Thaumatin2-Pgi2 & Antixenosis (oviposition)/CL & 15.6 & 17.4 & 0.0002 & 2.8 & -25.3 \\
\hline qBPH6-2 & Thaumatin2-Pgi2 & Antixenosis (oviposition)/IRRI & 14.1 & 16.0 & 0.0003 & 2.8 & -26.5 \\
\hline qBPH6-3 & Thaumatin2-Pgi2 & Plant reaction to feeding/Seedbox, CL & 13.3 & 12.5 & 0.002 & 2.6 & -0.38 \\
\hline $\mathrm{qBPH} 11^{\mathrm{j}}$ & ZmDRTse-r2 & Plant reaction to feeding/Seedbox, $\mathrm{CL}$ & 22.6 & 20.6 & $<0.0001$ & 4.3 & -0.47 \\
\hline $\mathrm{qBPH} 12-1^{\mathrm{j}}$ & ZmDRTsd-S2AS3A5 & Plant reaction to feeding/Seedbox, CL & 17.6 & 16.9 & 0.0001 & 2.9 & -0.43 \\
\hline $\mathrm{qBPH} 12-2^{\mathrm{j}}$ & PK1K2I4-rNBS14 & Plant reaction to feeding/Seedbox, IRRI & 20.3 & 18.6 & $<0.0001$ & 4.5 & -0.55 \\
\hline qBPH12-3 $3^{j}$ & RG181-XLRfrI2 & Antixenosis (settling)/IRRI & 10.9 & 11.3 & 0.001 & 2.5 & -0.73 \\
\hline
\end{tabular}

a QTL are named based on McCouch (1997).

${ }^{\mathrm{b}}$ Markers defining QTL, where the first named marker in the interval is the most significant in single-point linkage tests.

${ }^{\mathrm{c}}$ Tests conducted with BPH populations from International Rice Research Institute (IRRI) and Central Luzon (CL), Philippines.

${ }^{\mathrm{d}} F_{\mathrm{c}}=$ regression mean square/error mean square.

${ }^{\mathrm{e}} R^{2}=$ regression sum of square/total sum of square.

${ }^{\mathrm{f}} P$ (probability) is the level of significance when the computed $\mathrm{F}$ value is compared to the tabular $\mathrm{F}$ value.

${ }^{\mathrm{g}} \mathrm{LOD}=\log _{10}$ likelihood ratio.

${ }^{\text {h }}$ Effect of IR64 allele. For all traits, lower phenotypic values indicate greater resistance to BPH.

${ }^{\mathrm{i}}$ Based on simple regression analysis, qBPH3 is associated with RG191 $(P=0.01)$. However, based on a permutation test $(P=0.05)$, the association of qBPH3 with the RG191 is not significant.

${ }^{j}$ QTL regions newly identified from IR64 × Azucena DH population using Qgene analysis (Nelson 1997). These QTL regions were not identified in Alam and Cohen (1998) using MLE in Mapmaker (Lander et. al. 1987). 
pCR 2.1-TOPO (Invitrogen, Carlsbad, CA, U.S.A.). Each insert of appropriate size was sequenced in United States Department of Agriculture DNA sequencing facilities at Kansas State University.

DNA from parents of the DH mapping population (IR64 and Azucena) were digested with six restriction enzymes, HindIII, $X b a \mathrm{I}, E c o \mathrm{RV}$, EcoRI, DraI, and ScaI, and analyzed using candidate genes as probes to detect polymorphism, following standard RFLP techniques (Sambrook et al. 1989). If polymorphism was detected between the parents, progeny DNA was digested with the appropriate enzyme and, after hybridization, segregation patterns were scored in the progeny.

To obtain PCR markers corresponding to RGAs, primer pairs were designed from conserved motifs of LRR, NBS, and kinase domains as previously described (Chen et al. 1998). Seven primer pairs were used to amplify DNA from the parental lines and DH progeny. Primers AS1 (5'-CAACGCTAGTGGCAATCC- $3^{\prime}$ ) and AS2 (5'-IAGIGCAGIGGIAGICC-3') were designed from the NBS region of RPS2 from an Arabidopsis sp. and $N$ from tobacco (Leister et al. 1996); primers S1 (5'GGTGGGGTTGGGAAGACAACG-3') and S2 (5'-CAICAIAAIGGITGIGGIGG-3') were designed from the NBS domain of RPS2 from an Arabidopsis sp. (Leister et al. 1996); and primers NLRR-for (5'-TAGGGCCTCTTGCATCGT-3'), NLRRrev (5' -TATAAAAAGTGCCGGACT-3'), NLRR-INV1 (5'-TGCTACGTTCTCCGGG-3'), and NLRR-INV2 (5'-TCAGGCCGTGAAAAATAT-3') were designed from the LRR region of the tobacco $N$ gene (H. Leung, unpublished data). Primers PtoKin-1 and PtoKin-2 were designed from the kinase domain of Pto from tomato (Chen et al. 1998), and XLRR-for (5'-CCGTTGGACAGGAAGGAG-3'), XLRR-rev (5'-CCCATAGACCGGACTGTT-3'), XLRR-INV1 (5'-TTGTCAGGCCAGATACCC-3'), and XLRR-INV2 (5'-GAGGAAGGACAGGTTGCC-3') were designed from the LRR region of $\mathrm{Xa} 21$ from rice (H. Leung, unpublished data). The amplified fragments were resolved by polyacrylamide gel electrophoresis and visualized by silver staining. Only markers that were reproducible in more than two runs were used for mapping.

\section{Map construction, candidate gene association, and statistical analysis.}

Markers were placed on a linkage map that consisted of 175 anchor markers including both RFLP and isozymes (Huang et al. 1994). Linkage relationships between the anchored markers and candidate gene markers produced by this study were generated using Mapmaker, Macintosh version 2.0 (Lander et al. 1987), setting the LOD at 3.0. Map distances were estimated by the Kosambi function (Kosambi 2002). Different linkage groups were assigned to each chromosome according to the location of RFLP anchor markers. The orientation of the linkage groups in chromosomes 1, 2, 4, 7, 10, and 11 were reversed following centromere mapping of Singh and associates (1996).

The insect and disease phenotype and QTL data were obtained from direct evaluation of $\mathrm{BB}$ and $\mathrm{BPH}$ on the $\mathrm{DH}$ lines (discussed above). The position of major resistance genes for blast and $\mathrm{BB}$ were derived from published papers and the Gramene database. QTL positions for blast (Prashanth et al. 1998; Wang et al. 1994) and sheath blight (Zou et al. 2000) resistance were previously reported.

The frame map generated from the above analysis was used to detect association of candidate genes with $\mathrm{BB}$ and $\mathrm{BPH}$ resistance using QGene v2.26 (Nelson 1997). To identify candidate genes associated with resistance at the 0.01 level of probability, a simple regression analysis was used. A permutation test for simple regression analysis using SAS (v8.2) was performed to determine the appropriate threshold value. The process was repeated 100 times, and the resulting top $10 R^{2}$ values were selected to compare the threshold $R^{2}$ value with that of the original $R^{2}$ for each marker or defense gene associated with BPH and BB QTLs. If the threshold value for each trait was less than the $R^{2}$ of the original data, then the association between the marker and the trait was not significant at $P=0.05$.

Single-point analysis was performed to determine multipleregression models for different markers. Interval-regression mapping was performed on selected linkage groups with markers that showed significant single-factor effects. The choice of LOD cutoff values (2.4 and 1.8 for $\mathrm{BPH}$ and BB QTL, respectively) was based on the contour map resulting from interval mapping. Only candidate genes with single-factor significance of $P<0.01$ in interval regression maps of selected chromosomes were shown as putative QTL in the map. Association with major genes and previously reported QTL were done by visual inspection of the published maps with the aid of markers common to both studies. Thus, the location of the reported QTL and major genes are approximates as defined by the available common markers.

\section{ACKNOWLEDGMENTS}

This work was partially supported by a Boyscast fellowship, Government of India (J. Ramalingam), a Rockefeller Foundation postdoctoral fellowship (K. Kukreja), a Kansas State University Biotechnology Center Grant (J. M. Chittoor), the National Science Foundation (S. H. Hulbert and J. E. Leach), the U.S. Agency for International Development, the Asian Rice Biotechnology Network supported by the Asian Development Bank, and the Kansas Agricultural Experiment Station (02-427-J). We thank our many colleagues who generously provided cloned genes to build the Kansas State University defense gene collection and made their clones available for use by multiple collaborators, M. Ramos and M. Villamayor for their technical assistance in QTL analysis, B. Bartolome for statistical analysis, and P. Manosalva and E. Boyko for their excellent reviews of the manuscript.

\section{LITERATURE CITED}

Ahn, S., and Tanksley, S. D. 1993. Comparative linkage maps of the rice and maize genomes. Proc. Natl. Acad. Sci. U.S.A. 90:7980-7984.

Alam, S. N., and Cohen, M. B. 1998. Detection and analysis of QTLs for resistance to the brown planthopper, Nilaparvata lugens, in a doubledhaploid rice population. Theor. Appl. Genet. 97:1370-1379.

Albar, L., Lorieux, M., Ahmadi, N., Rimbault, I., Pinel, A., Sy, A. A., Fargette, D., and Ghesquiere, A. 1998. Genetic basis and mapping of the resistance to rice yellow mottle virus. I. QTLs identification and relationship between resistance and plant morphology. Theor. Appl. Genet. 97:1145-1154.

Anderson, P. A., Lawrence, G. J., Morrish, B. C., Ayliffe, M. A., Finnegan, E. J., and Ellis, J. G. 1997. Inactivation of the flax rust resistance gene $M$ associated with loss of a repeated unit within the leucine-rich repeat coding region. Plant Cell 9:641-651.

Bai, J., Pennill, L., Ning, J., Lee, S. W., Ramalingam, J., Webb, C. R., Zhao, B., Sun, Q., Nelson, J. C., Leach, J. E., and Hulbert, S. H. Diversity in nucleotide binding site-leucine-rich repeat genes in cereals. Genome Res. In press.

Bartels, D., Engelhardt, K., Roncarati, R., Schneider, K., Rotter, M., and Salamini, F. 1991. An ABA and GA modulated gene expressed in the barley embryo encodes an aldose reductase related protein. EMBO (eur. Mol. Biol. Organ.) J. 10:1037-1043.

Bent, A. F., Kunkel, B. N., Dahlbeck, D., Brown, K. L., Schmidt, R., Giraudat, J., Leung, J., and Staskawicz, B. J. 1994. RPS2 of Arabidopsis thaliana: A leucine-rich repeat class of plant disease resistance genes. Science 265:1856-1860.

Boyko, E., Kalendar, R., Korzun, V., Fellers, J., Korol, A., Schulman, A., and Gill, B. 2002. A high-density cytogenetic map of the Aegilops tauschii genome incorporating retrotransposons and defense-related genes: Insights into cereal chromosome structure and function. Plant Mol. Biol. 48:767-790.

Byrne, P. F., McMullen, M. D., Snook, M. E., Musket, T. A., Theuri, J. M., Widstrom, N. W., Wiseman, B. R., and Coe, E. H. 1996. Quantitative trait loci and metabolic pathways: Genetic control of the concentration of maysin, a corn earworm resistance factor, in maize silks. Proc. Natl. Acad. Sci. U.S.A. 93:8820-8825. 
Chen, X. M., Line, R., and Leung, H. 1998. Genome scanning for disease resistance gene analogs in wheat, barley and rice by high-resolution electrophoresis. Theor. Appl. Genet. 97:345-355.

Chittoor, J. M., Leach, J. E., and White, F. F. 1997. Differential induction of a peroxidase gene family during infection of rice by Xanthomonas oryzae pv. oryzae. Mol. Plant-Microbe Interact. 10:861-871.

Collins, N. C., Webb, C. A., Seah, S., Ellis, J. G., Hulbert, S. H., and Pryor, A. 1998. The isolation and mapping of disease resistance gene analogs in maize. Mol. Plant-Microbe Interact. 11:968-978.

Colrat, S., Latche, A., Guis, M., Pech, J.-C., Bouzayen, M., Fallot, J., and Roustan, J.-P. 1999. Purification and characterization of a NADPH-dependent aldehyde reductase from mung bean that detoxifies eutypine, a toxin from Eutypa lata. Plant Physiol. 119:621-626.

Courtois, B., McLaren, G., Sinha, P. K., Prasad, K., Yadav, R., and Shen, L. 2000. Mapping QTLs associated with drought avoidance in upland rice. Mol. Breed. 6:55-66.

Cox, K., Robertson, D., and Fites, R. 1999. Mapping and expression of bifunctional thymidylate synthase, dihydrofolate reductase gene from maize. Plant Mol. Biol. 41:733-739.

Devos, K. M., and Gale, M. D. 2000. Genome relationships: The grass model in current research. Plant Cell 12:637-646.

Dixon, R. 2001. Natural products and plant disease resistance. Nature 411:843-847.

Dixon, R. A., and Harrison, M. J. 1990. Activation, structure, and organization of genes involved in microbial defense in plants. Adv. Genet. 28:165-234.

Dumas, B., Freysinet, G., and Pallett, K. E. 1995. Tissue-specific expression of germin-like oxalate oxidase during development and fungal infection of barley seedlings. Plant Physiol. 107:1091-1096.

Ellis, J., and Jones, D. 1998. Structure and function of proteins controlling strain-specific pathogen resistance in plants. Curr. Opin. Plant Biol. 1:288-293.

Epple, P., Apel, K., and Bohlmann, H. 1997. Overexpression of an endogenous thionin enhances resistance of Arabidopsis against Fusarium oxysporum. Plant Cell 9:509-520.

Faris, J. D., Li, W. L., Liu, D. J., Chen, P. D., and Gill, B. S. 1999. Candidate gene analysis of quantitative disease resistance in wheat. Theor. Appl. Genet. 98:219-225.

Garcia-Mas, J., van Leeuwen, H., Monfort, A., deVicente, C. Puigdomenech, P., and Arus, P. 2001. Cloning and mapping of resistance gene homologues in melon. Plant Sci. 161:165-172.

Geffroy, V., Sevignac, M., deOliveira, J., Fouilloux, G., Skroch, P. Thoquet, P., Gepts, P., Langin, T., and Dron, M. 2000. Inheritance of partial resistance against Colletotrichum lindemuthianum in Phaseolus vulgaris and co-localization of quantitative trait loci with genes involved in specific resistance. Mol. Plant-Microbe Interact. 3:287-296.

Goff, S., Ricke, D., Lan, T. H., Presting, G., Wang, R., Dunn, M., Glazebrook, J., Sessions, A., Oeller, P., Varma, H., Hadley, D., Hutchison, D., Martin, C., Katagiri, F., Lange, B. M., Moughamer, T., Xia, Y., Budworth, P., Zhong, J., Miguel, T., Paszkowski, U., Zhang, S., Colbert, T. G., Sun, W. L., Chen, L., Cooper, B., Park, S., Wood, T. C., Mao, L., Quail, P., Wing, R., Dean, R., Yu, Y., Zharkikh, A., Shen, R., Sahasrabudhe, S., Thomas, A., Cannings, R., Gutin, A., Pruss, D., Reid, J., Tavtigian, S., Mitchell, J., Eldredge, G., Scholl, T., Miller, R. M., Bhatnager, S., Adey, N., Rubano, T., Tusneem, N., Robinson, R., Feldhaus, J., Macalma, T., Oliphant, A., and Briggs, S. 2002. A draft sequence of the rice genomes (Oryzae sativa L. ssp. japonica). Science 296:92-100

Guiderdoni, E., Galinato, E., Luistro, J., and Vergara, G. 1992. Anther culture of tropical japonica/indica hybrids of rice (Oryzae sativa L.). Euphytica 62:219-224.

Hain, R., Reif, H.-J., Krause, E., Langebartels, R., Kindl, H., Vornam, B., Wiese, W., Schmelzer, E., Schreier, P. H., Stöcker, R. H., and Stenzel, K. 1993. Disease resistance results from foreign phytoalexin expression in a novel plant. Nature 361:153-156.

Hilaire, E., Young, S. A., Willard, L. H., McGee, J. D., Sweat, T., Chittoor, J. M., Guikema, J., and Leach, J. E. 2001. Vascular defense responses in rice: Peroxidase accumulation in xylem parenchyma cells and xylem wall thickening. Mol. Plant-Microbe Interact. 14:14111419.

Huang, N., McCouch, S., Mew, T., Parco, A., and Guiderdoni, E. 1994. Development of an RFLP map from a doubled haploid population in rice. Rice Genet. Newsl. 11:134-137.

Huang, N., Parco, A., Mew, T., Magpantay G., McCouch, S., Guiderdoni, E., Xu, J., Subudhi, P., Angeles, E. R., and Khush, G. S. 1997. RFLP mapping of isozymes, RAPD and QTLs for grain shape, brown planthopper resistance in a doubled haploid rice population. Mol. Breed. 3:105-113.

Huh, J., Kang, B., Nahm, S., Kim, S., Ha, K., Lee, M. H., and Kim, B. D. 2001. A candidate gene approach identified phytoene synthase as the locus for mature fruit color in red pepper (Capsicum spp.). Theor Appl. Genet. 102:524-530.

Hulbert, S. H., Webb, C. A., Smith, S. M., and Sun Q. 2001. Resistance gene complexes: Evolution and utilization. Annu. Rev. Phytopathol. 39:285-312.

Kanazin, V., Marek, L. F., and Shoemaker, R. C. 1996. Resistance gene analogs are conserved and clustered in soybean. Proc. Natl. Acad. Sci. U.S.A. 93:11746-11750.

Kauffman, H. E., Reddy, A. P. K., Hsiek, S. P. V., and Marca, S. D. 1973. An improved technique for evaluating resistance of race varieties to Xanthomonas oryzae. Plant Dis. Rep. 57:537-541.

Koch, M., and Parlevliet, J. E. 1991. Residual effects of the Xa4 resistance gene in three rice cultivars when exposed to a virulent isolate of Xanthomonas campestris pv. oryzae. Euphytica 55:187-193.

Kosambi, D. D. 2002. The estimation of map distances from recombination values. Ann. Eugen. 12:172-175.

Lamb, C., and Dixon, R. A. 1997. The oxidative burst in plant disease resistance. Annu. Rev. Plant Physiol. Plant Mol. Biol. 48:251-275.

Lander, E. S., Green, P., Abrahamson, J., Barlow, A., Daly, M. J., Lincoln, S. E., and Etoh, T. 1987. MAPMAKER: An interactive computer package for constructing primary genetic linkage maps of experimental and natural populations. Genomics 1:174-181.

Leister, D., Ballvora, A., Salamini, F., and Gebhardt, C. 1996. A PCRbased approach for isolating pathogen resistance genes from potato with potential for wide application in plants. Nat. Genet. 14:421-429.

Leister, D., Kurth, J., Laurie, D. A., Yano, M., Sasaki, T., Devos, K. Graner, A., and Schulze-Lefert, P. 1998. Rapid reorganization of resistance gene homologues in cereal genomes. Proc. Natl. Acad. Sci. U.S.A. 95:370-375.

Leister, D., Kurth, J., Laurie, D. A., Yano, M., Sasaki, T., Graner, A., and Schulze-Lefert. 1999. RFLP and physical mapping of resistance gene homologues in rice $(O$. sativa) and Barley (H. vulgare). Theor. Appl. Genet. 98:509-520.

Leung, H., Wu, C., Baraoidan, M. R., Bordeos, A., Ramos, M., Madamba, S., Cabauatan, P., Vera Cruz, C. M., Portugal, A., Reves, G., Bruskiewich, R., McLaren, G., Gregorio, G., Bennett, J., Brar, D., Khush, G., Schnable, P., Wang, G. L., and Leach, J. E. 2001. Deletion mutants for functional genomics: Progress in phenotyping, sequence assignment, and database development. Pages 239-251. in: Rice Genetics IV. Science Publishers, Inc, New Delhi.

Li, B., and Foley, M. E. 1995. Cloning and characterization of differentially expressed genes in imbibed dormant and afterripened Avena fatura embryos. Plant Mol. Biol. 29:823-831.

Liang, H., Maynard, C., Allen, R., and Powell W. 2001. Increased Septoria musiva resistance in transgenic hybrid poplar leaves expressing a wheat oxalate oxidase gene. Plant Mol. Biol. 45:619-629.

Mago, R., Nair S, and Mohan M. 1999. Resistance gene analogues from rice: Cloning, sequencing and mapping. Theor. Appl. Genet. 99:50-57.

Malehorn, D., Borgmeyer, J. R., Smith, C. E., and Shah, D. M. 1994. Characterization and expression of an antifungal zeamatin-like protein (Zlp) gene from Zea mays. Plant Physiol. 106:1471-1481.

Martin, T. J., and Ellingboe, A. H. 1976. Differences between compatible parasite/host genotypes involving the Pm4 locus of wheat and the corresponding genes in Erysiphe graminis f. sp. tritici. Phytopathology $66: 1435-1438$

McCouch, S., Cho, Y. G., Yano, M., Paul, E., Blinstrub, M., Morishima, H., and Kinoshita, T. 1997. Report on QTL nomenclature. Rice Genet. Newsl. 14:11-13.

McMullen, M. D., Byrne, P. F., Snook, B. R., Wiseman, B. R., Lee, E. A., Widstrom, N. W., and Coe, E. H. 1998. Quantitative trait loci and metabolic pathways. Proc. Natl. Acad. Sci. U.S.A. 95:1996-2000.

McMullen, M. D., and Simcox, K. 1995. Genomic organization of disease and insect resistance genes in maize. Mol. Plant-Microbe Interact. 8:811-815.

Meeley, R. B., Johal, G. S., Briggs, S. P., and Walton, J. D. 1992. A biochemical phenotype for a disease resistance gene of maize. Plant Cell 4:71-77.

Mehdy, M. C. 1994. Active oxygen species in plant defense against pathogens. Plant Physiol. 105:467-472.

Ming, R., Brewbaker, J., Pratt, R. C., Musket, T. A., and McMullen, M. D. 1997. Molecular mapping of a major gene conferring resistance to maize mosaic virus. Theor. Appl. Genet. 95:271-275.

Nelson, J. C. 1997. QGENE: Software for marker-based genomic analysis and breeding. Mol. Breed. 3:239-245.

Nelson, R. R. 1972. Stabilizing racial populations of plant pathogens by use of resistance genes. J. Environ. Qual. 1:220-227.

Nicholson, R. L., and Hammerschmidt, R. 1992. Phenolic compounds and their role in disease resistance. Annu. Rev. Phytopathol. 30:369 389.

Ochman, H., Elwyn, S., and Moran, N. A. 1999. Calibrating bacterial 
evolution. Proc. Natl. Acad. Sci. U.S.A. 96:12638-12643.

Pan, Q., Wendel, J., and Fluhr, R. 2000. Divergent evolution of plant NBS-LRR resistance gene homologues in dicot and cereal genomes. J. Mol. Evol. 50:203-213.

Pflieger, S., Lefebvre, V., Caranta, C., Blattes, A., Goffinet, B., and Palloix, A. 1999. Disease resistance gene analogs as candidates for QTLs involved in pepper-pathogen interactions. Genome 42:11001110.

Pierpoint, W. S., Jackson, P. J., and Evans, R. M. 1990. The presence of a thaumatin-like protein, a chitinase and a glucanase among the pathogenesis-related proteins of potato (Solanum turberosum). Physiol. Mol. Plant Pathol. 36:325-338.

Prashanth, G. B., Hittalmani, S., Srinivasachary, K., Shadakshari, H., and Shashidhar, H. E. 1998. Genetic markers associated with field resistance to leaf and neck blast across locations in rice (Oryzae sativa L.). Rice Genet. Newsl. 15:128-131.

Ronald, P. C. 1998. Resistance gene evolution. Curr. Opin. Plant Biol 1:294-298.

Rossi, M., Goggin, F. L., Milligan, S. B., Kaloshian, I., Ullman, D. E., and Williamson, V. M. 1998. The nematode resistance gene $M i$ of tomato confers resistance against the potato aphid. Proc. Natl. Acad. Sci. U.S.A. 95:9750-9754

Saghai-Maroof, M. A., Soliman, K. M., Jorgensen, R. A., and Allard, R. W. 1984. Ribosomal DNA spacer-length polymorphisms in barley: Mendelian inheritance, chromosomal location, and population dynamics. Proc. Natl. Acad. Sci. U.S.A. 81:8014-8018.

Sambrook, J., Fritsch, E. F., and Maniatis, T. 1989. Molecular Cloning: A Laboratory Manual. Cold Spring Harbor Laboratory, Cold Spring Harbor, NY

Singh, K., Ishii, T., Parco, A., Huang, N., Brar, D. S., and Khush, G. S. 1996. Centromere mapping and orientation of the molecular linkage map of rice (Oryzae sativa L.). Proc. Natl. Acad. Sci. U.S.A. 93:61636168.

Tenhaken, R., Levine, A., Brisson, L. F., Dixon, R. A., and Lamb, C. 1995. Function of oxidative burst in hypersensitive disease resistance. Proc. Natl. Acad. Sci. U.S.A. 92:4158-4163.

Thorup, T. A., Tanyolac, B., Livingstone, K. D., Popovsky, S., Paran, I., and Jahn, M. 2000. Candidate gene analysis of organ pigmentation loci in the Solanaceae. Proc. Natl. Acad. Sci. U.S.A. 97:11192-11197.

Toojinda, T., Broers, L. H., Chen, X. M., Hayes, P. M., Kleinhofs, A., Korte, J., Kudrna, D., Leung, H., Line, R., Powell W., Ramsey, L., Vivar, H., and Waugh, R. 2001. Mapping quantitative and qualitative disease resistance genes in a doubled haploid population of barley (Hordeum vulgare). Theor. Appl. Genet. 101:580-589.

Trognitz, F., Manosalva, P., Gysin, R., Niño-Liu, Simon, R., Herrera, M., Trognitz, B., Ghislain, M., and Nelson, R. 2002. Plant defense genes associated with quantitative resistance to potato late blight in Solanum phureja X dihaploid S. tuberosum hybrids. Mol. Plant-Microbe Interact. 15:587-597.

van der Wel, H., and Loeve, K. 1972. Isolation and characterization of thaumatin I and II, the sweet tasting proteins from Thaumatococcus danielli Benth. J. Biochem. 31:221-225.

Vandiver, V. V., and Fites, R. C. 1979. Thymidylate synthase activity from chlamydomonas cells and cultured tissues of Nicotiana, Pinus, and Daucus. Plant Physiol. 64:668-670.

Velazhahan, R., Chen-Cole, K., Anuratha, C. S., and Muthukrishnan, S. 1998. Induction of thaumatin-like proteins (TLPs) in Rhizoctonia solani-infected rice and characterization of two new cDNA clones. Physiol. Plant. 102:21-28.

Vigers, A. J., Wiedemann, S., Roberts, W. K., Legrand, M., Selitrennikoff, C. P., and Fritig, B. 1992. Thaumatin-like pathogenesisrelated proteins are antifungal. Plant Sci. 83:155-161.

Vos, P., Simons, G., Jesse, T., Wijbrandi, J., Heinen, L., Hogers, R., Frijters, A., Groenendijk, J., Diergaarde, P., Reijans, M., FierensOnstenk, J., de Both, M., Peleman, J., Liharska, T., Hontelez, J., and Zabeau, M. 1998. The tomato Mi-1 gene confers resistance to both root-knot nematodes and potato aphids. Nat. Biotechnol. 16:13651369.
Walling, L. L. 2000. The myriad plant responses to herbivores. J. Plant Growth Regul. 19:195-216.

Wang, G., Mackill, D. J., Bonman, J. M., McCouch, S. R., and Nelson, R. J. 1994. RFLP mapping of genes conferring complete and partial resistance to blast resistance in a durably resistant rice cultivar. Genetics 136:1421-1434.

Wang, Z., Taramino, G., Yang, D., Liu, G., Tingey, S., Miao, G., and Wang, G. 2001. Rice ESTs with disease-resistance gene-or defenseresponse gene-like sequences mapped to regions containing major resistance genes or QTLs. Mol. Genet. Genomics 265:310.

Webb, C. A., Richter, T. E., Collins, N. C. Nicolas, M., Trick, H. N. Pryor, T., and Hulbert, S. H. 2002. Genetic and molecular characterization of the maize rp3 rust resistance locus. Genetics 162:381-394.

Woloshuk, C. P., Meulenhoff, E. J. S., Sela-Buurlage, M., Van den Elzen, P., and Cornelissen, B. 1991. Pathogen-induced proteins with inhibitory activity toward Phytophthora infestans. Plant Cell 3:619628.

Wu, G., Shortt, B. J., Lawrence, E. B., León, J., Fitzsimmons, K. C., Levine, E. B., Raskin, I., and Shah, D. M. 1997. Activation of host defense mechanisms by elevated production of $\mathrm{H}_{2} \mathrm{O}_{2}$ in transgenic plants. Plant Physiol. 115:427-435.

Xu, M. L., Melchinger, A. E., Xia, X. C., and Lübberstedt, T. 1999. Highresolution mapping of loci conferring resistance to sugarcane mosaic virus in maize using RFLP, SSR, and AFLP markers. Mol. Gen. Genet. 261:574-581.

Yoshimura, A., Lei, J. X., Matsumoto, T., Tsunematsu, H., Yoshimura, S., Iwata, N., Baraoidan, M. R., Mew, T. W., and Nelson, R. J. 1996. Analysis and pyramiding of bacterial blight resistance genes in rice by using DNA markers. Pages 577-581. in: Rice Genetics III. International Rice Research Institute, Manila, The Philippines.

Young, N. D. 1996. QTL mapping and quantitative disease resistance in plants. Annu. Rev. Phytopathol. 34:479-501.

Yu, J., Hu, S., Wang, J., Wong, G. K., Li, S., Liu, B., Deng, Y., Dai, L., Zhou, Y., Zhang, X., Cao, M., Liu, J., Sun, J., Tang, J., Chen, Y., Huang, X., Lin, W., Ye, C., Tong, W., Cong, L., Geng, J., Han, Y., Li, L., Li, W., Hu, G., Huang, X., Li, W., Li, J., Liu, Z., Li, L., Liu, J., Qi, Q., Liu, J., Li, L., Li, T., Wang, X., Lu, H., Wu, T., Zhu, M., Ni, P., Han, H., Dong, W., Ren, X., Feng, X., Cui, P., Li, X., Wang, H., Xu, X., Zhai, W., Xu, Z., Zhang, J., He, S., Zhang, J., Xu, J., Zhang, K. Zheng, X., Dong, J., Zeng, W., Tao, L., Ye, J., Tan, J., Ren, X., Chen, X., He, J., Liu, D., Tian, W., Tian, C., Xia, H., Bao, Q., Li, G., Gao, H., Cao, T., Wang, J., Zhao, W., Li, P., Chen, W., Wang, X., Zhang, Y., Hu, J., Wang, J., Liu, S., Yang, J., Zhang, G., Xiong, Y., Li, Z., Mao, L., Zhou, C., Zhu, Z., Chen, R., Hao, B., Zheng, W., Chen, S., Guo, W., Li, G., Liu, S., Tao, M., Wang, J., Zhu, L., Yuan, L., and Yang, H. 2002. A draft sequence of the rice genome (Oryzae sativa L. ssp. indica). Science 296:79-92.

Yu, Y. G., Buss, G. R., and Maroof Saghai, M. A. 1996. Isolation of a superfamily of candidate disease-resistance genes in soybean based on a conserved nucleotide-binding site. Proc. Natl. Acad. Sci U.S.A. 93:11751-11756.

Zhang, Z., Collinge, D. B., and Thordal-Christensen, H. 1995. Germinlike oxalate oxidase, a $\mathrm{H}_{2} \mathrm{O}_{2}$-producing enzyme, accumulates in barley attacked by the powdery mildew fungus. Plant J. 8:139-145.

Zhou, F., Zhang, Z., Gregersen, L., Mikkelsen, J. D., de Neergaard, E. Collinge, D. B., and Thordal-Christensen, H. 1998. Molecular characterization of the oxalate oxidase involved in the response of barley to the powdery mildew fungus. Plant Physiol. 117:33-41.

Zou, J. H., Pan, X. B., Chen, Z., Xu, J. Y., Lu, J. F., Zhai, W. X., and Zhu, L. H. 2000. Mapping quantitative trait loci controlling sheath blight resistance in two rice cultivars (Oryzae sativa L.). Theor. Appl. Genet. 101:569-573

\section{AUTHOR-RECOMMENDED INTERNET RESOURCES}

Kansa State University defense gene collection: www.ksu.edu/ksudgc Gramene database: www.gramene.org 